\title{
The Individualistic Roots of Virtue
}

\author{
YVONNE CHIU
}

\section{The Familial Roots of Universal Care}

Although Bai says that his main target is democracy, he turns much of his attention to liberalism, rejecting its foundational value of autonomy in favor of Confucian grounds for governance. In his Mencian theory of hybrid meritocratic democracy, the government promotes morality and enables the people's moral education, while compassion and humaneness are the 'social glue in the society of strangers' (Bai 2019: 110).

Ensuing action is separate from sentiment, however. There are limits to what people will actually $d o$ for others even if they feel compassion, Mencius acknowledges, so action must be cultivated by 'grow[ing]' the 'universal "seed of humaneness"' (Bai 2019: 125) through the vehicle of the family, which serves as the centerpiece of political society.

Family is one's first and closest community, and familial affection is 'almost as natural as one's self-love,' says Bai, so it is a natural 'stepping stone' for expanding one's love to family and community (which will be as far as most people can extend their concern), and then perhaps for some to the broader society, state, and world (Bai 2019: 126-7).

People naturally think family is special, so it is difficult to expand the scope of one's compassion, and Bai rejects as inaccurately 'mechanical' the 'concentric circle' model of spheres of compassion. Instead, expansion of care happens more by analogy, as concern for the distant 'is rooted in our care for' those who are close to us (Bai 2019: 125-37, 138): familial love is the foundation of patriotism (love of state/society), which then grounds concern for foreigners. One is still justified in caring more for family because roots are necessarily stronger. Universal care is 'graded and hierarchical,' Mencius and Bai remind us, and is not the same as universal or egalitarian love (Bai 2019: 133).

The analogous process, however, only highlights the difficulty of extending compassionate humaneness toward strangers. Even if the scope of feeling successfully expands, it is a separate matter to then broaden the scope of one's actions accordingly, for actions do not necessarily follow.

This hierarchy of action is also not analogous to the hierarchy of care. It is not simply that one should do less for those more distant - as physical distance constrains anyway - just as one should care less for them, but rather that one would calculate the trade-offs differently. This makes concern for the distant not just lesser, but also distinctive. And even as Confucian compassion and humaneness limit what can be done for the state, hierarchy of action means that proper care for one's own family/community may sometimes pose irreconcilable trade-offs that justify actively harming those outside of it. Can that be reconciled with even hierarchical 'universal care,' if universal care requires more than sentiment and should be accompanied by meaningful action/inaction? 
Furthermore, there are serious questions about the very nature of the familial love that grounds Mencian political society. First, it is important to recognize that Confucian universal humaneness's roots lie not in familial care but rather in self-love. And as only self-love is completely natural and sprouts all other care, it should, as the root of the plant, be strongest within the hierarchy of universal care, and stronger than familial care. Confucians would argue that self-love consistent with Confucian virtues would be quite different from liberal conceptions of self-love, of course, but this alone begins to narrow the gap between Confucianism and liberalism in a way that Confucians might be uncomfortable with.

In addition, self-love can also be the analogous root of indifference. People become inured to the suffering of others, which is, ironically, part and parcel of resilience on one's own behalf: they acclimate to it the same way they adapt to their own challenges (e.g., persistent scarcity or physical insecurity), especially if it is systematic, institutionalized, and/or widespread. So the root of the plant of compassion does not always yield care and concern.

When it comes to family, that love is also not monolithic. Bai offers an insightful interpretation of Confucian emphasis on filial care: Confucianism espouses reciprocity rather than unilateral obedience to one's parents/superiors, but because parental care for children is natural, Confucianism pays it less attention, and focuses on the less instinctual care of adult children for their parents. If Bai's interpretation is correct, however, then familial love is not monolithic, and less natural than it initially appears.

Neither does concern for others always diminish with (physical or metaphorical) distance from oneself. People are often more patient and generous with and kinder to strangers than to their own family, with whom they can have a long history of bad interactions, misunderstandings, hurt feelings, and ill-will. ${ }^{1}$

Both self-love and familial love as well as their relationships to care for strangers are more complicated than acknowledged, ${ }^{2}$ which raises some doubts about grounding Mencian democracy and its complex societal apparatus on compassion and humaneness that is rooted in self-love and must be cultivated in the familial training ground.

\section{The Liberal Project and its Confucian Affinities}

Contemporary critics of liberalism - communitarians, leftists, egalitarians, conservatives, and fascists alike - frequently focus on its atomizing effects in practice. Bai does the same, and misses the mark in similar ways.

Common to these critiques are the understanding of liberal individualism as 'the primacy of one's self-interest' and the 'sole moral basis of a liberal democratic state,' and the belief that this 'radical individualism...destroy[s] all authorities except for...the tyrannical power of the crude and unchecked narrow self-interest' (Bai 2019: 168). Eventually, says Bai, there is only 'unrestrained pursuit of short-term material interests in the free market,' where people free-ride on each other (Bai 2019: 169).

\section{Compassion and Humaneness}

This stark and alarming vision of liberal society is, however, not quite accurate. Implementation always falls short of the ideal, even in Confucian-based societies. The question is whether the practices necessarily follow from the theory in a way that demonstrates a fundamental flaw in the model. In liberalism's case, it does not seem so, because the reality is not as dire as critics claim. 
In providing basic security, for example, Bai doubts whether militaries comprised of democratic individualists could possibly 'defeat an army from a state that celebrates the love of one's country and the common good' (Bai 2019: 169). Individualism and patriotism are not mutually exclusive, however: contrary to authoritarian societies' reputation for military superiority because they are more disciplined and cohesive, democracies have in fact won about eighty percent of the wars in the past two centuries. ${ }^{3}$

A similarly counter-intuitive story is found on the homefront. The archetype of selfish, radical liberal individualism, the United States, scores as the most generous country in terms of charitable contributions over the past decade, 2010-2019 (Charities Aid Foundation 2019). ${ }^{4}$ Moreover, the top ten countries - United States, New Zealand, Ireland, United Kingdom, Sri Lanka, Myanmar, Australia, Canada, Netherlands, and Indonesia - are diverse, not all of them wealthy, but most of them liberal democracies. Democratic liberal individualism does not inevitably lead to equal disregard for others, and compassion and humaneness can flourish alongside whatever radical individualism might also exist.

\section{The Importance of Liberal Virtues}

Just as it does Confucianism a disservice to charge it with blind obedience to parents and rulers, critics mischaracterize liberalism in blaming it for radical individualism. Like Confucianism, the liberal tradition has great concern for cultivating virtue and self-discipline.

Liberals such as John Locke, Immanuel Kant, and Friedrich Hayek commonly emphasize that no liberty is possible without laws and norms. They would agree with Bai that the right institutions alone are insufficient - institutions are only as good as the people who operate them, so they need a 'thickened morality' that will both uphold the institution and be thin enough to accord with liberalism. It is not just 'moral conservatives and...leftists' who care about promoting virtues and public interest (Bai 2019: 279).

\section{The Nature of Liberal Autonomy}

But do Confucians and liberals share compatible visions of what those moral virtues should be? There may not be room for either moral or personal autonomy in Confucianism (Chiu 2017), but one must reject liberalism for the right reasons and with an accurate conception of the moral and personal autonomy it champions. Bai's characterization of liberal autonomy as 'each individual [being] the master of his or her own fate' is a misunderstanding. Neither moral autonomy nor personal autonomy are radical expressions of one's will. Rather, moral autonomy is self-legislation and requires not just reflective engagement with and voluntary endorsement of morality, but also locating one's moral law within one's own moral agency. Personal autonomy entails choosing one's own projects and commitments, but actively shaping one's own identity is still constrained by the realm of physical possibility and one's other priorities such as family. In no sense do liberals believe that there is even an abstract right to have whatever one wants. One may not choose to pursue 'the good,' as Confucians prescribe, but neither is personal autonomy an exercise of Nietzschean radicalism.

In the view of authors such as Adam Smith, Immanuel Kant, and J.S. Mill, liberal autonomy should be used in part to develop certain virtues. For example, self-command is essential to freedom, says Smith, and natural feelings of sympathy (care for others) and shame, pride, and amiability help keep people in check and should be reinforced: people naturally crave approval from others, for 'humanity does not desire to be great, but to be beloved. It is not 
in being rich that truth and justice would rejoice, but in being trusted and believed' ([TMS III.5.8] Smith 1982: 166-8).

Both older and contemporary liberals including Alexis de Tocqueville, J.S. Mill, and David Miller also value communities, borders, and nations. Making stark distinctions between public and private provides a conceptual touchstone that acknowledges an important distinction and the hard choices that sometimes have to be made in trading off the two, as liberalism confronts the confounding role of the family (Okin 1989) and of 'special obligations' to kin and community (Scheffler 2001).

Thus, liberal pursuit of self-interest leads not necessarily to rampant rapaciousness, but often to cultivation of personal relationships, familial bonds, camaraderie, and community.

\section{The God of Mammon}

Despite Confucianism's general support for markets and private property, Bai and others are suspicious of economic markets and their colonization of all spheres of life. 'The economic free market may have destroyed the free marketplace of ideas,' he worries, and 'liberal value neutrality...doesn't allow the state to challenge the formidable force of the free market by promoting certain values of the Good' (Bai 2019: 169).

Communal ideals can flourish in a free market, however. Morality and virtue may have difficulty seizing market share, but they can have some market power, as evidenced by the recent rise of divestment movements and 'socially responsible' investment funds. Shortcomings lie not with the market per se, which is a clearinghouse for people's preferences, but rather with the people who participate in the market.

But what if the people are flawed? What if their vices dominate the marketplace of ideas and values? Liberalism does not reify the market and whatever demands it produces. The liberal state can promote certain conceptions of the good: liberal communitarians, especially Michael Walzer $(1983,1990)$ and Charles Taylor (1989), are clear that liberalism cannot be neutral all the way down, because it can be practiced only when people share fundamental liberal values.

'State value neutrality' with respect to the good tries to prevent authoritarian rule, to avoid government-capture by a single sectarian group promoting one conception of the good to the exclusion of others. Neutrality with respect to the good does not mean indifference to matters of right and justice, however, and liberalism is capable of distinguishing between the good and the right.

A negative aim is not the same as having no values or being value-neutral: on the contrary, value judgements are essential to prevent or stop injustices. To that end, J.S. Mill's plural perfectionist utilitarianism echoes Mencius's belief that all people could - or at least should - cultivate their moral virtues; Mill considered that so important that he advocated plural voting ${ }^{5}$ as well as education to inculcate fellow-feeling and sympathy (so that one could take on board others' pains and pleasures), to such a degree that individualism might not be unleashed but rather smothered. So it is mistaken to think that liberalism has no content; far from justifying the 'evasion of virtues in the public sphere,' virtuousness must sustain a genuinely liberal public sphere.

\section{Conclusion}

The first half of Bai's book targets democracy, and that is where his critiques and argument for a hybrid meritocratic democracy hit the hardest. His criticisms of liberalism, however, engage 
only such an extreme conception of it that they miss the mark, and unnecessarily so for his purposes. ${ }^{6}$ Worshipping at the altar of Mammon and the problem of the ignorant and disengaged wielding political power are common to humanity, across all societal types. More so than liberal democracy, it seems that the real target of Bai's criticisms about individualism is rather populism, which requires neither liberalism nor democracy to take root.

Given the extent of his concurrence with liberalism, it would be more consistent with Bai's stated aim of tempering the democratic part and shoring up the liberal side of liberal democracy to make common cause with liberalism against populism. Mencian compassion and humaneness have much to add to liberal conversation about virtue, for example by pushing conceptions of altruism beyond a self-interest-based framework while remaining secular. By building on their shared affinities, a Mencian-liberal theory of governance could yield the Confucian ideal of 'harmony without uniformity,' for resolution in harmonic music is most effective when it reconciles a dissonant chord that precedes it.

\section{ORCID}

Yvonne Chiu (D) https://orcid.org/0000-0002-8641-3628

\section{Notes}

1. One study of donor choice in charitable giving found that donors scoring higher on an 'empathic concern' scale are more likely to give to international than to domestic relief causes (Neumayr and Handy 2019).

2. If charitable giving is a partial proxy for humaneness and compassion, they have a complex relationship with family - as well as with gender, age, religious belief, and religious attendance. The formation of one's own family (through marriage) has significant positive effects on generosity in the West: married people engage in more charitable activity (giving and volunteering), but the amounts and probability increase significantly for married men and decrease somewhat for married women, in comparison to their single counterparts. Notably, almost all of the additional charitable activity is for religious cause and the difference disappears once religious attendance is controlled for (Eagle et al 2018; Einolf and Philbrick 2014; Musick and Wilson 2008; Neumayr and Handy 2019; Wiepking and James 2013). In the West, at least, religious community - as opposed to mere religious belief - is doing a lot of the work, and religious giving and volunteering comprises the bulk of charitable activity in the U.S. One question is whether the same level of compassionate action could be achieved with non-religious

3. Ponds $1816-1990$, democracies won $93 \%$ of the wars they initiated, and $63 \%$ of ones in which they were targeted, compared with dictatorships and oligarchies (Reiter and Stam 2002).

4. While the US's vast wealth might account for much of its generosity, in fact about $70 \%$ of charitable funds come from individuals, not corporations or foundations, and are spread across two-thirds of American households. (National Philanthropic Trust; Philanthropy Roundtable (a); Philanthropy Roundtable (b)).

5. Liberalism and Confucianism's shared affinity for meritocracy is not entirely a thing of the past: there is a robust contemporary literature on epistemic democracy and moreover 'epistocracy' by authors such as Joshua Cohen, James Fishkin, David Estlund, and Dimitri Landa and Ryan Pevnick.

6. Similarly, it is unnecessary to claim that 'after Mao, the Chinese regime has gradually gone back more and more to the Confucian understanding of the legitimacy of governance' (Bai 2019: 167), which is controversial at best and in reality outright incorrect, or to posit a golden age of virtuous hierarchical role morality in which peasants in the past respected authority, as peasants had no choice but to respect power, which often fancies itself to carry authority.

\section{Bibliography}

Bai, T. (2019), Against Political Equality: The Confucian Case. Princeton and Oxford: Princeton University Press.

Charities Aid Foundation (2019), CAF World Giving Index, 10th Edition, https://www.cafonline.org/about-us/ publications/2019-publications/caf-world-giving-index-10th-edition (last accessed 24 September 2021). 
Chiu, Y. (2017), 'Democracy without Autonomy: Moral and Personal Autonomy in Democratic Confucianism,' Philosophy East \& West, 67:1, pp. 47-60.

Eagle, D., L.A. Keister, and J. Ghazal Read (2018), 'Household Charitable Giving at the Intersection of Gender, Marital Status, and Religion,' Nonprofit and Voluntary Sector Quarterly, 47: 1, pp. 185-205.

Einolf, C.J. and D. Philbrick (2014), 'Generous or Greedy Marriage? A Longitudinal Study of Volunteering and Charitable Giving,' Journal of Marriage and Family, 76: 3, pp. 573-586.

Musick, M. and J. Wilson (2008), Volunteering: A social profile, Bloomington IN: Indiana University Press.

National Philanthropic Trust, 'Charitable Giving Statistics,' https://www.nptrust.org/philanthropic-resources/charitable-giving-statistics/ (last accessed 24 September 2021).

Neumayr, M. and F. Handy (2019), 'Charitable Giving: What Influences Donors' Choice among Different Causes?, VOLUNTAS: International Journal of Voluntary and Nonprofit Organizations, 30: 4, pp. 783-799.

Okin S. M. (1989), Justice, Gender, and the Family. New York NY: Basic Books.

Philanthropy Roundtable (a), 'Who Gives Most to Charity?,' https://www.philanthropyroundtable.org/almanac/ statistics/u.s.-generosity (last accessed 24 September 2021).

Philanthropy Roundtable (b), Almanac, https://www.philanthropyroundtable.org/almanac (last accessed 24 September 2021).

Reiter, D. and Allan C. Stam (2002), Democracies at War, Princeton NJ: Princeton University Press.

Scheffler, S. (2001), Boundaries and allegiances: Problems of justice and responsibility in liberal thought, New York NY: Oxford University Press.

Smith, A. (1982), The Theory of Moral Sentiments ed. D.D. Raphael and A.L. Macfie, Indianapolis IN: Liberty Fund Press. [Original work published 1759 first edition, 1790 sixth edition]

Taylor, C. (1989), 'Cross-Purposes: The Liberal-Communitarian Debate' in Liberalism and the Moral Life (N. Rosenblum, ed.), Cambridge, MA: Harvard University Press.

Walzer, M. (1983), Spheres of Justice. New York NY: Basic Books.

Walzer, M. (1990), 'The Communitarian Critique of Liberalism,' Political Theory 18:1, pp. 6-23.

Wiepking, P and R. James (2013), 'Why are the Oldest Old Less Generous? Explanations for the Unexpected Age-Related Drop in Charitable Giving,' Ageing and Society, 33: 3, pp. 486-510. 